\title{
Leitthema
}

coloproctology $2020 \cdot 42: 24-29$

https://doi.org/10.1007/s00053-019-00420-0

Published online: 29 November 2019

(c) The Author(s) 2019

\author{
A. Sunny ${ }^{1}$ H. Sellars ${ }^{1} \cdot$ G. Ramsay ${ }^{1,2} \cdot$ R. Polson ${ }^{3} \cdot$ A. J. M. Watson \\ ${ }^{1}$ Colorectal Surgery, Raigmore Hospital, Inverness, UK \\ ${ }^{2}$ Rowett Institute, University of Aberdeen, Aberdeen, UK \\ ${ }^{3}$ Highland Health Sciences Library, Centre for Health Science, Inverness, UK
}

\section{Who needs a stapling device for haemorrhoidectomy, if one has the radiofrequency device?}

$\mathrm{MeSH}$ terms and keywords. The three components of each search were haemorrhoids, radiofrequency (RF) or named devices and stapled, procedure for prolapse and haemorrhoids (PPH) or Longo procedure.

Following the initial searches, references were examined via the abstract. Studies containing primary outcome data or secondary analyses comparing $\mathrm{SH}$ with $\mathrm{RFH}$ were included and full texts retrieved. The relevance and completeness of the published data were reviewed. Studies with significant missing methodological information, outcome data or statistical analyses were subsequently excluded. The citations and references of included papers were searched for further relevant studies. - Fig. 1 shows the Preferred Reporting Items for Systematic Reviews and Meta-Analyses (PRISMA) chart for this work.

\section{Results}

There were 11 relevant papers in this review, including six randomised controlled trials (RCTs) published between 2005 and 2018 with a total of 457 patients. In addition, there were five systematic reviews and meta-analysis on the subject, one of which is a network meta-analysis included in the discussion. the Milligan-Morgan [10], Ferguson [6], and Parks procedures [12] performed with diathermy, scissors or scalpels. The most common problems are postoperative pain and bleeding. More recent techniques such as stapled haemorrhoidopexy (SH) and haemorrhoidectomy using a radiofrequency device (RFH) were developed to reduce these complications.

Herein, we aim to look at the evidence comparing $\mathrm{SH}$ to $\mathrm{RFH}$ with respect to complications, outcomes, patient experiences and costs.

\section{Materials and methods}

A literature review was performed using multiple databases: Ovid MEDLINE, CINAHL, SCOPUS, PROSPERO, Cochrane library, EMBASE, World of Knowledge and PubMed. The search strategy was tailored for each database and, where feasible, combined both

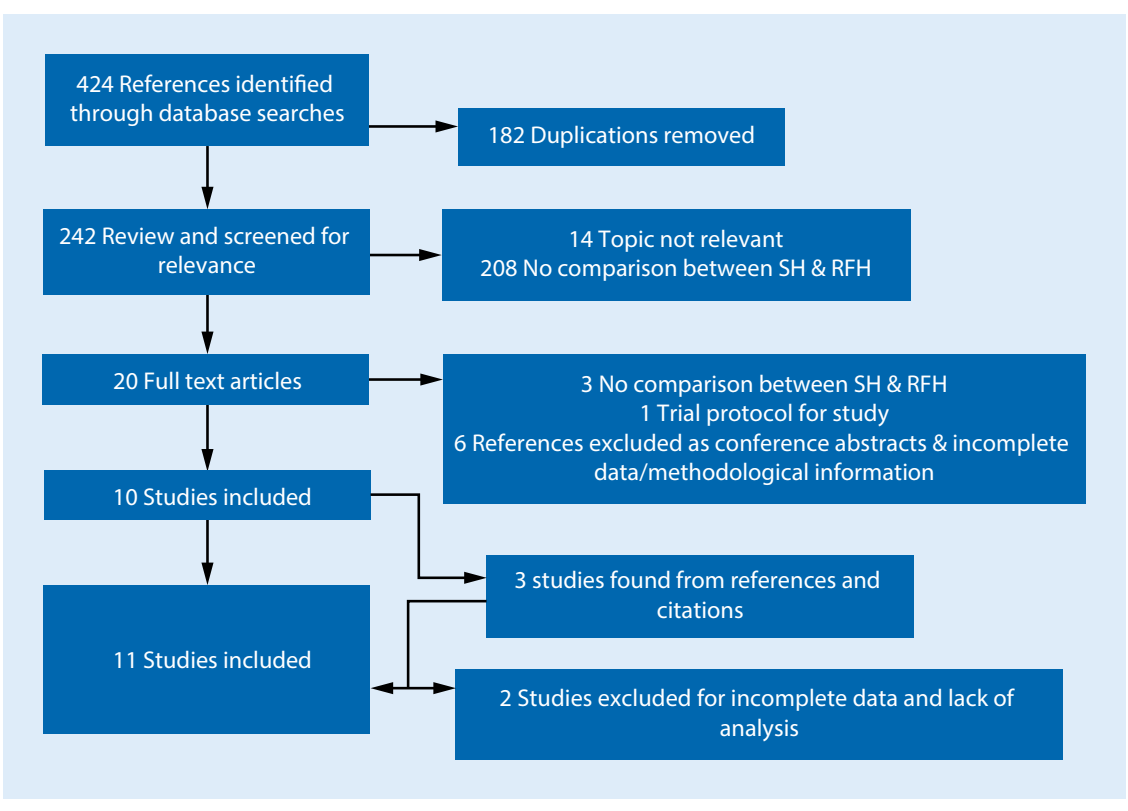

Fig. 1 ॥ PRISMA chart of the results of the search strategy and identification of relevant studies. SH stapled haemorrhoidopexy, $R F H$ radiofrequency haemorrhoidectomy 


\begin{tabular}{|c|c|c|c|c|c|c|c|c|c|c|c|}
\hline Authors & Year & Country & $\begin{array}{l}\text { Study } \\
\text { type }\end{array}$ & $\begin{array}{l}\text { Nun } \\
\text { tien }\end{array}$ & $\begin{array}{l}\text { of pa- } \\
\text { study }\end{array}$ & Stapler & $\begin{array}{l}\text { RF } \\
\text { device }\end{array}$ & $\begin{array}{l}\text { Grade of } \\
\text { haemorrhoid } \\
\text { included }\end{array}$ & $\begin{array}{l}\text { Follow-up } \\
\text { period }\end{array}$ & $\begin{array}{l}\text { Sex } \\
M / F\end{array}$ & $\begin{array}{l}\text { Age } \\
\text { Mean, } \\
\text { years } \\
\text { (range) }\end{array}$ \\
\hline $\begin{array}{l}\text { Arslani } \\
\text { et al. [1] }\end{array}$ & 2012 & Croatia & RCT & 98 & $\begin{array}{l}\mathrm{SH}=46 \\
\mathrm{RFH}=52\end{array}$ & PPH03 & LigaSure & Grade 3 & 24 months & $\begin{array}{l}\mathrm{SH}=21 / 25 \\
\mathrm{RFH}=23 / 29\end{array}$ & $\begin{array}{l}52(17-72) \\
50(18-78)\end{array}$ \\
\hline $\begin{array}{l}\text { Basdanis } \\
\text { et al. [2] }\end{array}$ & 2005 & Greece & RCT & 95 & $\begin{array}{l}\mathrm{SH}=50 \\
\mathrm{RFH}=45\end{array}$ & PPH01 & LigaSure & Grade $3 \& 4$ & 18 months & $\begin{array}{l}\mathrm{SH}=29 / 21 \\
\mathrm{RFH}=25 / 20\end{array}$ & $\begin{array}{l}46(25-72) \\
44(22-69)\end{array}$ \\
\hline $\begin{array}{l}\text { Chen et al. } \\
\text { [4] }\end{array}$ & 2007 & China & $\mathrm{RCT}$ & 86 & $\begin{array}{l}\mathrm{SH}=44 \\
\mathrm{RFH}=42\end{array}$ & Not stated & LigaSure & Grade 3 & 6 months & $\begin{array}{l}\mathrm{SH}=26 / 18 \\
\mathrm{RFH}=24 / 18\end{array}$ & $\begin{array}{l}48(25-81) \\
46(23-85)\end{array}$ \\
\hline $\begin{array}{l}\text { Ibrahim } \\
\text { et al. [7] }\end{array}$ & 2018 & Egypt & $\mathrm{RCT}$ & 60 & $\begin{array}{l}\mathrm{SH}=30 \\
\mathrm{RFH}=30\end{array}$ & AVENTAL & LigaSure & Grade $3 \& 4$ & Not stated & $\begin{array}{l}\mathrm{SH}=20 / 10 \\
\mathrm{RFH}=18 / 12\end{array}$ & $\begin{array}{l}40(20-60) \\
38(18-55)\end{array}$ \\
\hline $\begin{array}{l}\text { Kraemer } \\
\text { et al. [8] }\end{array}$ & 2005 & Germany & $\mathrm{RCT}$ & 50 & $\begin{array}{l}\mathrm{SH}=25 \\
\mathrm{RFH}=25\end{array}$ & $\begin{array}{l}\text { Ethicon } \\
\text { (device not } \\
\text { stated) }\end{array}$ & LigaSure & Grade $3 \& 4$ & 6 weeks & $\begin{array}{l}\mathrm{SH}=14 / 11 \\
\mathrm{RFH}=13 / 12\end{array}$ & $\begin{array}{l}58(40-71) \\
48(28-82)\end{array}$ \\
\hline $\begin{array}{l}\text { Sakr et al. } \\
\text { [14] }\end{array}$ & 2010 & Kuwait & $\mathrm{RCT}$ & 68 & $\begin{array}{l}\mathrm{SH}=34 \\
\mathrm{RFH}=34\end{array}$ & $\begin{array}{l}\text { Ethicon } \\
\text { (device not } \\
\text { stated) }\end{array}$ & LigaSure & Grade $3 \& 4$ & 18 months & $\begin{array}{l}\mathrm{SH}=21 / 13 \\
\mathrm{RFH}=19 / 15\end{array}$ & $\begin{array}{l}44(29-56) \\
39(33-52)\end{array}$ \\
\hline
\end{tabular}

Table 2 Summary of the five systematic reviews and meta-analysis directly comparing SH and RFH

\begin{tabular}{|c|c|c|c|c|}
\hline Authors & Year & Number of patients & Comparison & Relevant studies included \\
\hline Chen et al. [4] & 2014 & 397 & LigaSure versus stapled & $\begin{array}{l}\text { Arslani [1], Basdanis [2], Chen [4], Kraemer [8], } \\
\text { Sakr [14] }\end{array}$ \\
\hline Lee et al. [9] & 2013 & 311 & LigaSure versus stapled & Arslani [1], Basdanis [2], Kraemer [8], Sakr [14] \\
\hline $\begin{array}{l}\text { Milito et al. } \\
\text { [11] }\end{array}$ & 2008 & $\begin{array}{l}50 \text { direct comparisons, wider } \\
\text { analysis } 850\end{array}$ & LigaSure versus conventional & Kraemer [8] \\
\hline $\begin{array}{l}\text { Similis et al. } \\
{[15]}\end{array}$ & 2015 & $\begin{array}{l}397 \text { direct comparisons, } \\
\text { wider analysis } 7827\end{array}$ & $\begin{array}{l}\text { Surgical treatments for haemor- } \\
\text { rhoids-Network meta-analysis }\end{array}$ & $\begin{array}{l}\text { Arslani [1], Basdanis [2], Chen [4], Kraemer [8], } \\
\text { Sakr [14] (98 trials in total) }\end{array}$ \\
\hline Yang et al. [18] & 2013 & 397 & LigaSure versus stapled & $\begin{array}{l}\text { Arslani [1], Basdanis [2], Chen [4], Kraemer [8], } \\
\text { Sakr [14] }\end{array}$ \\
\hline
\end{tabular}

\section{Primary data}

There were six RCTs identified with primary data included in the review, as summarised in $\bullet$ Table 1.

\section{Secondary analysis}

A total of five systematic reviews and meta-analysis were found to compare $\mathrm{SH}$ with RFH, as summarised in • Table 2. These all included the relevant studies at the time of their publication; however, none included all six papers.

\section{Intraoperative experience}

Two of the studies reported on intraoperative outcomes. Basdanis et al. [2] recorded episodes of intraoperative bleeding, occurring in $36 \%$ of stapled procedures compared to $8.8 \%$ in the LigaSure (Medtronic, Minneapolis, $\mathrm{MN}$, USA) group, $P<0.05$. Kraemer et al. [8] also evaluated the ease of handling and immediate operative result as rated by the operating surgeon. There was no significant difference between the groups $(P=0.5535$ for ease of use or $P=0.4384$ for immediate results).

Five studies referred to operating times $[2,4,7,8,14]$; the findings were conflicting, with studies favouring different groups. The difference between approaches ranged from 2 to $7 \mathrm{~min}$, and is therefore not clinically relevant.

\section{Postoperative complications}

\section{Pain}

Postoperative pain is a major problem associated with haemorrhoidectomy. Both $\mathrm{SH}$ and $\mathrm{RFH}$ have demonstrated lower pain scores compared to the conventional approach [15]. The RCTs mainly recorded analgesia use and pain scores on a visual analogue scale (VAS) at selected timepoints. The results are shown in - Table 3.

There are three studies that found increased early postoperative pain in the RFH group [2, 4, 7] during the first week after surgery, although no significant difference was identified in the other three trials $[1,8,14]$. 
coloproctology $2020 \cdot 42: 24-29$ https://doi.org/10.1007/s00053-019-00420-0

(c) The Author(s) 2019

\section{A. Sunny $\cdot$ H. Sellars · G. Ramsay $\cdot$ R. Polson · A. J. M. Watson}

\section{Who needs a stapling device for haemorrhoidectomy, if one has the radiofrequency device?}

\section{Abstract}

Background. Multiple operations exist to treat haemorrhoids. Although comparisons of conventional excision and other techniques have been performed, there are less comparative outcome data available for stapled haemorrhoidopexy (SH) and radiofrequency haemorrhoidectomy (RFH). Use of a radiofrequency energy device for haemorrhoidectomy is an alternative to standard diathermy, scissors or scalpel. It provides vessel sealing between the jaws of the instrument and aims to minimise wider tissue damage.

Objective. To systematically review the literature comparing $\mathrm{SH}$ and $\mathrm{RFH}$, assessing complications, outcomes, patient experience and costs.
Methods. A tailored search of medical databases identified literature containing relevant primary and secondary data comparing $\mathrm{SH}$ and RFH. Papers were screened for relevance and completeness of published data. Those missing methodological information, outcome data or statistical analysis were subsequently excluded. A narrative review was then performed.

Results. The primary data in this review originate from six randomised control trials (RCTs) and five meta-analyses. Evidence was conflicting, with a trend towards more early postoperative pain in the RFH vs. the SH group (three RCTs reported increased early pain scores in the RFH group). Significantly higher rates of residual and recurrent haemorrhoids and prolapse in the SH group were observed in two RCTs and four meta-analyses. Bleeding, urinary retention, incontinence and anal stenosis did not significantly differ. No detailed contemporary cost analysis was found.

Conclusion. The trials are small, with significant heterogeneity in the techniques used and outcome data recorded. However, despite the limited available evidence, RFH appears superior to SH due to significantly lower rates of residual and recurrent haemorrhoids and prolapse.

Keywords

Haemorrhoids · Pain - Cost · Postoperative complications · Prolapse

\section{Wer braucht einen Stapler zur Hämorrhoidektomie, wenn es das Hochfrequenzgerät gibt?}

\section{Zusammenfassung}

Hintergrund. Es gibt mehrere Operationsverfahren zur Behandlung von Hämorrhoiden. Vergleiche zwischen konventioneller Exzision und anderen Techniken wurden zwar durchgeführt, aber für die StaplerHämorrhoidopexie und die Hochfrequenzhämorrhoidektomie (RFH) sind wenig vergleichbare Ergebnisdaten verfügbar. Der Einsatz eines Hochfrequenzenergiegeräts für die Hämorrhoidektomie stellt eine Alternative zu Standarddiathermie, Schere oder Skalpell dar. Es ermöglicht den Gefäßverschluss zwischen den Backen des Instruments und zielt darauf ab, größere Gewebeschädigungen zu minimieren.

Ziel. Ziel war es, einen systematischen Überblick über die Literatur zum Vergleich von SH und RFH zu geben und dabei Komplikationen, Ergebnisse, Erfahrungen der Patienten und Kosten zu beurteilen.
Methoden. Durch eine passgenaue Suche in medizinischen Datenbanken wurden Publikationen mit relevanten Primär- und Sekundärdaten zum Vergleich von SH und RFH ermittelt. Die Arbeiten wurden in Bezug auf Relevanz und Vollständigkeit der veröffentlichten Daten überprüft. Arbeiten, in denen methodologische Informationen, Ergebnisdaten oder statistische Analysen fehlten, wurden anschließend aussortiert. Dann wurde eine narrative Übersicht erstellt. Ergebnisse. Die primären Daten in der vorliegenden Übersichtsarbeit stammen aus 6 randomisierten kontrollierten Studien (RCT) und Auswertungen. Die Evidenzlage war widersprüchlich, mit einer Tendenz in Richtung größerer früh postoperativer Schmerzen in der RFH- vs. SH-Gruppe (in 3 RCT wurde über steigende früh postoperative Schmerzscores in der RFH-Gruppe berichtet).
Signifikant höhere Raten an Residual- und Rezidivhämorrhoiden und -prolapsen in der SH-Gruppe wurden in den beiden RCT und den 4 Metaanalysen festgestellt. Die Daten zu Blutung, Harnretention, Inkontinenz und Analstenose unterschieden sich nicht signifikant. Es fand sich keine detaillierte aktuelle Kostenanalyse.

Schlussfolgerung. Die Studien sind von geringem Umfang, mit signifikanter Heterogenität in den verwendeten Techniken und aufgezeichneten Ergebnisdaten. Jedoch scheint die $\mathrm{RFH}$ trotz der begrenzten verfügbaren Evidenz der SH aufgrund signifikant niedrigerer Raten an Residual- und Rezidivhämorrhoiden und -prolapsen überlegen zu sein.

Schlüsselwörter

Hämorrhoiden · Schmerz · Kosten .

Postoperative Komplikationen · Prolaps
The data collected are heterogenous, with variations in technique and endpoints.

In contrast to the other studies, during $\mathrm{SH}$, Kraemer et al. [8] excised the external haemorrhoids with scissors. During haemorrhoidectomy with the radiofrequency device, Sakr et al. [14] used the conventional Milligan and Morgan technique with scissors below the dentate line and only applied the LigaSure device above the dentate line. However, three meta-analyses attempted to pool the data $[3,9,18]$, and all found no significant difference in postoperative pain between the two procedures.

The network meta-analysis by Simillis et al. [15] found significantly more postoperative pain following LigaSure haemorrhoidectomy compared to SH at day 14.

\section{Bleeding, urinary retention and incontinence}

Common early postoperative complications include bleeding, urinary retention and incontinence in particular; these are summarised in $\bullet$ Table 4.

There were no consistent differences between the approaches identified across the studies. The only significant finding was an increase in bleeding in the $\mathrm{SH}$ 


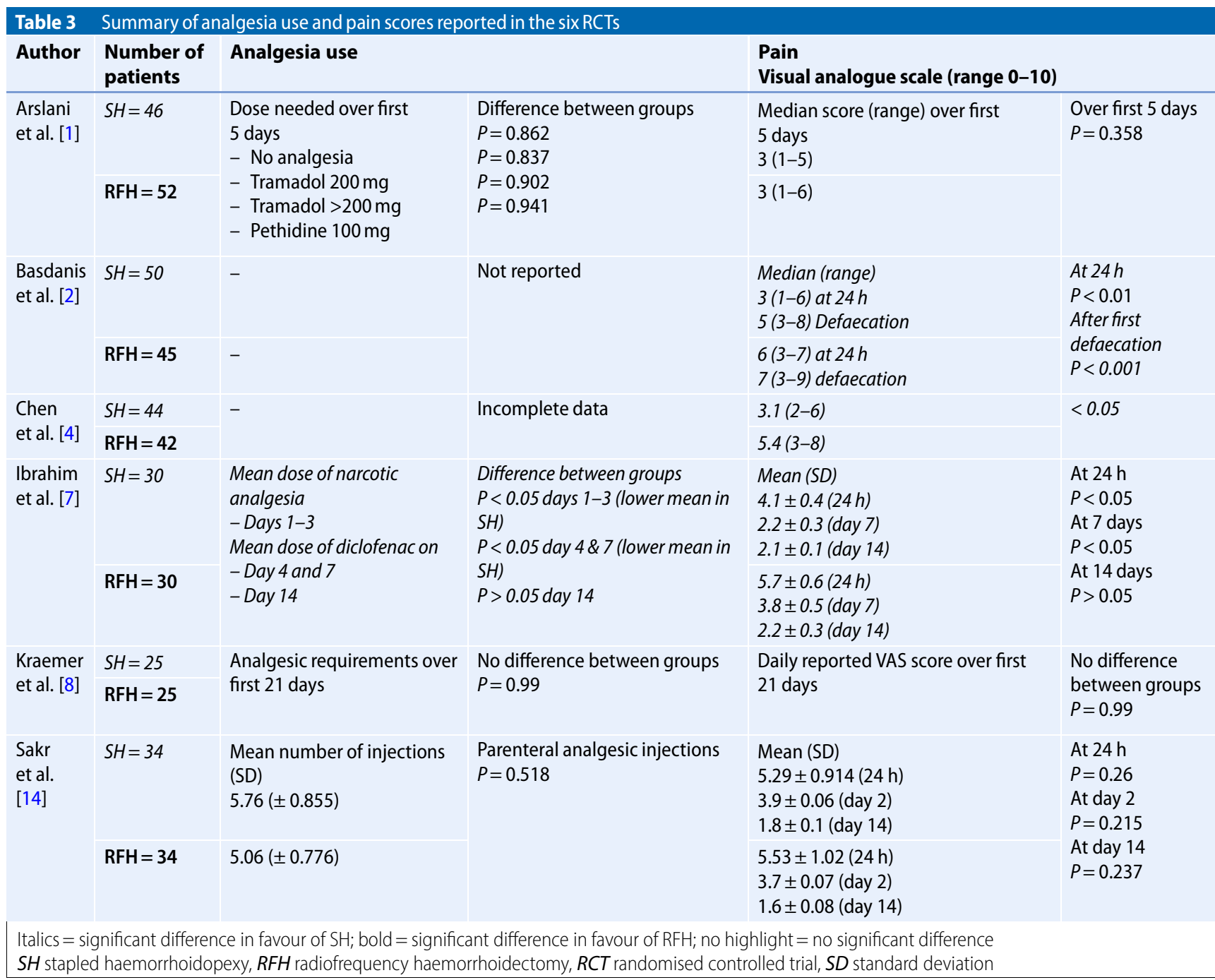

group by Chen et al. [4]. The meta-analyses pooled data across studies and did not identify any significant differences.

Basdanis et al. [2] also looked at anal manometry in postoperative patients, with no significant difference found between groups upon comparing mean resting anal pressures, maximum anal squeeze pressure and rectal compliance immediately postoperatively and after 1 month.

Two studies $[4,14]$ recorded constipation, wound infection and anal fissures, demonstrating no significant differences between the groups. However, Basdanis et al. [2] reported significantly increased itching and anorectal discharge immediately postoperatively in the radiofrequency device group. These differences were not present 1 month after surgery.

\section{Anal stenosis and recurrence}

Longer-term complications include anal stenosis and recurrence of both haemorrhoids and prolapse; these findings are summarised in 0 Table 5.

In two studies $[2,7]$ there were significantly higher rates of haemorrhoid recurrence and prolapse in the $\mathrm{SH}$ group. The meta-analyses by Chen [3] (odds ratio, OR, 0.18 for recurrence in $\mathrm{RFH}$, $P=0.01$ ), Lee [9] (OR 5.53 for recurrence in $\mathrm{SH}, P=0.016)$ and Yang et al. [18] (OR 0.21 for recurrence in RFH, $P=0.003$ ), and the network analysis by Simillis et al. [15] also found significantly higher recurrence rates in the SH compared to the RFH group. Residual prolapse and skin tags were recorded by two studies $[1,14]$, both of which found a signifi- cantly higher incidence in the $\mathrm{SH}$ group ( $P=0.04$ and $P=0.024$, respectively).

Life-threatening complications are rare after haemorrhoid surgery. Most case reports are associated with SH [13]. Rectal perforation, rectovaginal fistulae and sepsis have been reported, and there is an estimated $10 \%$ risk of mortality if the sepsis is secondary to $\mathrm{SH}$ [5]. None of these complications were identified in the presented studies.

\section{Patient experience}

Three studies referred to length of hospital stay $[2,7,14]$. There was no significant difference between the two groups, with results ranging from $20 \mathrm{~h}$ to 2.44 days. Four studies $[1,2,7,14]$ provided time to return to work or normal activities. The range of values lay between 6 days 
Table 4 Summary of common complications reported in the six RCTs

\begin{tabular}{|c|c|c|c|c|c|c|c|}
\hline \multirow{3}{*}{$\begin{array}{l}\text { Author } \\
\text { Arslani } \\
\text { et al. [1] }\end{array}$} & \multirow{2}{*}{$\begin{array}{l}\text { No. of patients in each } \\
\text { group } \\
S H=46\end{array}$} & \multicolumn{2}{|c|}{$\begin{array}{l}\text { Postoperative bleeding \% (no. of pa- } \\
\text { tients) }\end{array}$} & \multicolumn{2}{|c|}{$\begin{array}{l}\text { Postoperative urinary } \\
\text { retention }\end{array}$} & \multicolumn{2}{|c|}{$\begin{array}{l}\text { Postoperative } \\
\text { incontinence }\end{array}$} \\
\hline & & $\begin{array}{l}\text { Early } \\
6.5 \%(3) \\
\text { Late } \\
6.5 \% \text { (3) }\end{array}$ & $\begin{array}{l}\text { Early } P=0.504 \\
\text { Late } P=0.883\end{array}$ & $2.2 \%(1)$ & $P=0.898$ & $4.3 \%(2)$ & $P=0.919$ \\
\hline & $\mathrm{RFH}=52$ & $\begin{array}{l}\text { Early } \\
1.9 \%(1) \\
\text { Late } \\
3.8 \%(2)\end{array}$ & & $3.8 \%(2)$ & & $1.9 \%(1)$ & \\
\hline \multirow{2}{*}{$\begin{array}{l}\text { Basdanis } \\
\text { et al. [2] }\end{array}$} & $S H=50$ & $6 \%(3)$ & \multirow[t]{2}{*}{$P>0.05$} & $14 \%(7)$ & \multirow[t]{2}{*}{$P>0.05$} & $2 \%(1)$ & \multirow[t]{2}{*}{$P>0.05$} \\
\hline & $\mathrm{RFH}=45$ & $2.2 \%(1)$ & & $11.1 \%(5)$ & & $4.4 \%(2)$ & \\
\hline \multirow{2}{*}{$\begin{array}{l}\text { Chen } \\
\text { et al. [4] }\end{array}$} & $S H=44$ & $9.1 \%(4)$ & \multirow[t]{2}{*}{$P<0.05$} & - & \multirow[t]{2}{*}{-} & - & \multirow[t]{2}{*}{-} \\
\hline & $\mathrm{RFH}=42$ & $0 \%(0)$ & & - & & - & \\
\hline \multirow{2}{*}{$\begin{array}{l}\text { Ibrahim } \\
\text { et al. [7] }\end{array}$} & $S H=30$ & $6.7 \%(2)$ & \multirow[t]{2}{*}{$P>0.05$} & $6.7 \%(2)$ & \multirow[t]{2}{*}{$P>0.05$} & $3.3 \%(1)$ & \multirow[t]{2}{*}{$P>0.05$} \\
\hline & $\mathrm{RFH}=30$ & $3.3 \%(1)$ & & $10.0 \%(3)$ & & $6.7 \%(2)$ & \\
\hline \multirow{2}{*}{$\begin{array}{l}\text { Kraemer } \\
\text { et al. [8] }\end{array}$} & $S H=25$ & $0 \%(0)$ & \multirow[t]{2}{*}{$P>0.05$} & $16 \%(4)$ & \multirow[t]{2}{*}{$P>0.05$} & $0 \%(0)$ & \multirow[t]{2}{*}{$P>0.05$} \\
\hline & $\mathrm{RFH}=25$ & $4 \%(1)$ & & $8 \%(2)$ & & $0 \%(0)$ & \\
\hline \multirow{2}{*}{$\begin{array}{l}\text { Sakr et al. } \\
\text { [14] }\end{array}$} & $S H=34$ & $5.9 \%(2)$ & \multirow[t]{2}{*}{$P=0.555$} & $2.9 \%(1)$ & \multirow[t]{2}{*}{$P=0.555$} & $11.8 \%(4)$ & \multirow[t]{2}{*}{$P=0.393$} \\
\hline & $R F H=34$ & $2.9 \%(1)$ & & $5.9 \%(2)$ & & $5.9 \%(2)$ & \\
\hline
\end{tabular}

\begin{tabular}{|c|c|c|c|c|c|}
\hline \multirow{3}{*}{$\begin{array}{l}\text { Author } \\
\text { Arslani et al. } \\
\text { [1] }\end{array}$} & \multirow{3}{*}{$\begin{array}{l}\text { No. of patients in each } \\
\text { group } \\
\text { SH }=46 \\
\text { RFH }=52\end{array}$} & \multicolumn{2}{|c|}{ Anal stenosis } & \multicolumn{2}{|c|}{ Recurrence } \\
\hline & & \multirow{2}{*}{$\begin{array}{l}4.3 \%(2) \\
1.9 \%(1)\end{array}$} & \multirow[t]{2}{*}{$P=0.919$} & $11.1 \%(5)$ & \multirow[t]{2}{*}{$P=0.145$} \\
\hline & & & & $1.9 \%(1)$ & \\
\hline \multirow{2}{*}{$\begin{array}{l}\text { Basdanis et al. } \\
\text { [2] }\end{array}$} & $S H=50$ & - & \multirow[t]{2}{*}{-} & $6 \%(3)$ & \multirow[t]{2}{*}{$P<0.05$} \\
\hline & $\mathrm{RFH}=45$ & - & & $0 \%(0)$ & \\
\hline \multirow[t]{2}{*}{ Chen et al. [4] } & $S H=44$ & - & \multirow[t]{2}{*}{-} & $2.3(1)$ & \multirow[t]{2}{*}{$P>0.05$} \\
\hline & $\mathrm{RFH}=42$ & - & & $0 \%(0)$ & \\
\hline \multirow{2}{*}{$\begin{array}{l}\text { Ibrahim et al. } \\
\text { [7] }\end{array}$} & $S H=30$ & - & \multirow[t]{2}{*}{-} & $10.0 \%(3)$ & \multirow{2}{*}{$\begin{array}{l}\text { Prolapse } \\
\boldsymbol{P}<0.05\end{array}$} \\
\hline & $\mathrm{RFH}=30$ & - & & $3.3 \%(1)$ & \\
\hline \multirow{2}{*}{$\begin{array}{l}\text { Kraemer et al. } \\
\text { [8] }\end{array}$} & $S H=25$ & $4 \%(1)$ & \multirow[t]{2}{*}{$P>0.05$} & $0 \%(0)$ & \multirow[t]{2}{*}{$P>0.05$} \\
\hline & $\mathrm{RFH}=25$ & $0 \%(0)$ & & $0 \%(0)$ & \\
\hline \multirow[t]{2}{*}{ Sakr et al. [14] } & $S H=34$ & $5.9 \%(2)$ & \multirow[t]{2}{*}{$P=0.555$} & $11.8 \%(4)$ & \multirow[t]{2}{*}{$P=0.163$} \\
\hline & $\mathrm{RFH}=34$ & $2.9 \%(1)$ & & $2.9 \%(1)$ & \\
\hline \multicolumn{6}{|c|}{$\begin{array}{l}\text { Italics = significant difference in favour of SH; bold = significant difference in favour of RFH; no high- } \\
\text { light = no significant difference } \\
\text { SH stapled haemorrhoidopexy, RFH radiofrequency haemorrhoidectomy, RCT randomised con- } \\
\text { trolled trial }\end{array}$} \\
\hline
\end{tabular}

and 3 weeks, but none of these studies demonstrated a significant difference between the techniques.

Kraemer [8] and Chen et al. [4] both refer to patient satisfaction, with seemingly high self-reported scores and no significant differences between groups.

\section{Costs}

In 2004, Basdanis et al. [2] reports a surgical cost of 1175 Euros for SH and 780 Euros for RFH using the LigaSure device. With the addition of length of stay and medications, the costs were 1504 and 1268 Euros, respectively. Chen et al. [4] estimated the average costs for $\mathrm{SH}$ to be 748 Euros and for LigaSure to be 464 Eu- ros $(P<0.05)$ in 2007 (converted from Yuan based on 1 Yuan to 0.096 Euros). These are not contemporary prices; the range of products available has expanded and although the evidence presented is limited to the LigaSure device, cheaper devices and staplers are available. In view of this, without an up-to-date cost analysis, it is difficult to draw any conclusions.

\section{Discussion}

In this review, $\mathrm{SH}$ was associated with significantly higher rates of residual and recurrent haemorrhoids during followup compared to RFH, although RFH appeared to show higher early pain scores compared to the stapled group. The eTHoS trial [17] established the superiority of conventional haemorrhoidectomy over $\mathrm{SH}$, illustrating a similar picture of lower recurrence rates for the conventional technique, albeit with higher pain scores.

There were no significant differences in terms of hospital stay, return to work or normal activities and patient satisfaction, although no detailed quality of life data were recorded by any of the studies. Two studies compared costs; however, both are over 10 years old, and it is therefore 
unclear which procedure would be considered most cost-effective nowadays.

There are a number of limitations of the six RTCs included, particularly the small size, significant variation in techniques and heterogeneity of the outcomes measured. The only radiofrequency device used was the LigaSure.

\section{Conclusion}

Despite the limited evidence currently available, radiofrequency haemorrhoidectomy appears to be superior to stapled haemorrhoidopexy.

\section{Corresponding address}

\section{Prof. A. J. M. Watson}

Colorectal Surgery, Raigmore Hospital

Old Perth Rd, IV2 3UJ Inverness, Scotland, UK angus.watson@nhs.net

\section{Compliance with ethical guidelines}

Conflict of interest A. Sunny, H. Sellars, G. Ramsay, R. Polson and A.J.M. Watson declare that they have no competing interests.

For this article no studies with human participants or animals were performed by any of the authors. All studies performed were in accordance with the ethical standards indicated in each case.

Open Access. This article is distributed under the terms of the Creative Commons Attribution 4.0 International License (http://creativecommons.org/licenses/by/ $4.0 /$ ), which permits unrestricted use, distribution, and reproduction in any medium, provided you give appropriate credit to the original author(s) and the source, provide a link to the Creative Commons license, and indicate if changes were made.

\section{References}

1. Arslani N, Patrlj L, Rajkovi ÄZ, Pape ÅD, Altarac S (2012) A randomized clinical trial comparing ligasure versus stapled hemorrhoidectomy. Surg Laparosc Endosc Percutan Tech 22(1):58-61

2. Basdanis G, Papadopoulos VN, Michalopoulos A, Apostolidis S, Harlaftis N (2005) Randomized clinical trial of stapled hemorrhoidectomy vs open with Ligasure for prolapsed piles. Surg Endosc Interv Tech 19(2):235-239

3. Chen HL, Woo XB, Cui J, Chen CQ, Peng JS (2014) Ligasure versus stapled hemorrhoidectomy in the treatment of hemorrhoids: a meta-analysis of randomized control trials. Surg Laparosc Endosc Percutan Tech 24(4):285-289

4. ChenS, LaiD, Yang B,Zhang L,Zhou T, Chen G (2007) Therapeutic comparison between procedure for prolapse and hemorrhoids and Ligasure technique for hemorrhoids. Chin J Gastrointest Surg 10(4):342-345

5. Faucheron JL, Voirin D, Abba J (2012) Rectal perforation with life-threatening peritonitis following stapled haemorrhoidopexy. Br J Surg 99(6):746-753

6. Ferguson JA, Heaton JR (1959) Closed hemorrhoidectomy. Dis Colon Rectum 2(176):179

7. Ibrahim I, Metwalli A, Goda A (2018) LigaSure hemorrhoidectomy compared with stapled hemorrhoidopexy for management of grade III and IV hemorrhoids: A prospective randomized study. Life Sci J 15(4):92-99

8. Kraemer M, Parulava T, Roblick M, Duschka L, Muller-Lobeck H (2005) Prospective, randomized study: proximate PPH stapler vs. LigaSure for hemorrhoidal surgery. Dis Colon Rectum 48(8):1517-1522

9. Lee $\mathrm{KC}$, Chen $\mathrm{HH}$, Chung $\mathrm{KC}$, $\mathrm{Hu} \mathrm{WH}$, Chang $\mathrm{CL}$, Lin SE, Tsai KL, Lu CC (2013) Meta-analysis of randomized controlled trials comparing outcomes for stapled hemorrhoidopexy versus LigaSure hemorrhoidectomy for symptomatic hemorrhoids in adults. Int JSurg 11(9):914-918

10. Milligan ETC, Morgan CN, Jones LE, Officer $R$ (1937) Surgical anatomy of the anal canal and the operative treatment of hemorrhoids. Lancet 2:1119-1124

11. Milito G, Cadeddu F, Muzi MG, Nigro C, Farinon AM (2010) Haemorrhoidectomy with LigasureTM vs conventional excisional techniques: meta-analysis of randomized controlled trials. Colorectal Dis 12(2):85-93

12. Parks AG (1956) The surgical treatment of haemorrhoids. Br J Surg 43:337-351

13. Porrett LJ, Porrett JK, Ho YH (2015) Documented complications of staple hemorrhoidopexy: a systematic review. Int Surg 100(1):44-57

14. Sakr MF, Moussa MM (2010) LigaSure hemorrhoidectomy versus stapled hemorrhoidopexy: a prospective, randomized clinical trial. Dis Colon Rectum 53(8):1161-1167

15. Simillis C, Thoukididou SN, Slesser AAP, Rasheed S, Tan E, Tekkis PP (2015) Systematic review and network meta-analysis comparing clinical outcomes and effectiveness of surgical treatments for haemorrhoids. Br J Surg 102(13):1603-1618

16. van Tol RR, Bruijnen MPA, Melenhorst J, van Kuijk SMJ, Stassen LPS, Breukink SO (2018) A national evaluation of the management practices of hemorrhoidal disease in the Netherlands. Int J Colorectal Dis 33(5):577-588

17. Watson AJ, Hudson J, Wood J, Kilonzo M, Brown SR, McDonald A, Norrie J, Bruhn H, Cook JA, eTHoS study group (2016) Comparison of stapled haemorrhoidopexy with traditional excisional surgery for haemorrhoidal disease (eTHoS): a pragmatic, multicentre, randomised controlled trial. Lancet 388(10058):2375-2385

18. Yang J, Cui PJ, Han HZ, Tong DN (2013) Metaanalysis of stapled hemorrhoidopexy vs LigaSure hemorrhoidectomy. World J Gastroenterol 19(29):4799-4807
Hier steht eine Anzeige. Springer 